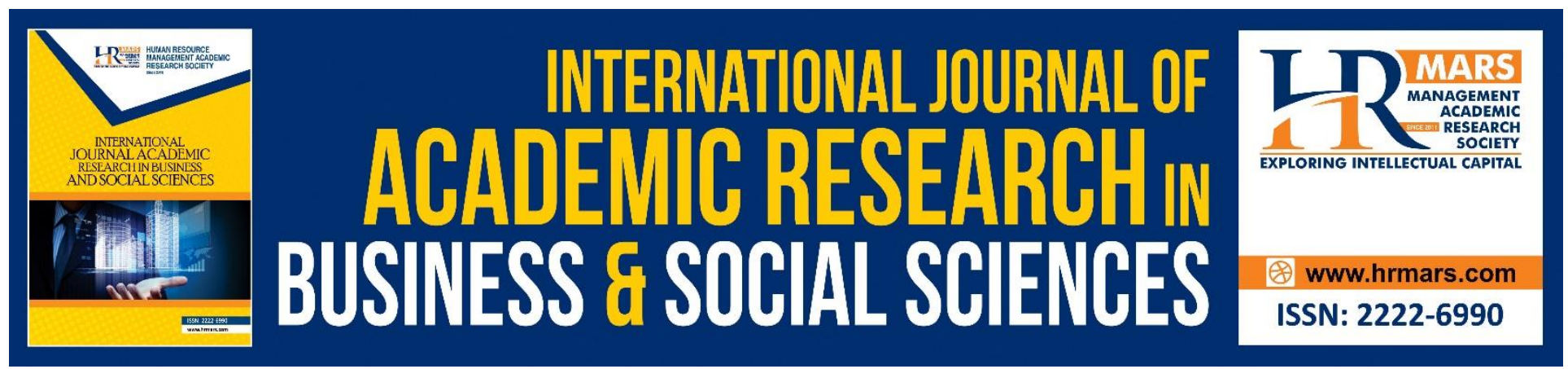

\title{
Thematic Study on Extrinsic Factors of Sexual Misconduct by Individuals with Autism
}

\section{Zuraini Yaakub, Zuliza Mohd Kusrin, Zaini Nasohah, Wafaa' Yusof}

To Link this Article: http://dx.doi.org/10.6007/IJARBSS/v10-i6/7470

DOI:10.6007/IJARBSS/v10-i6/7470

Received: 06 April 2020, Revised: 10 May 2020, Accepted: 03 June 2020

Published Online: 07 July 2020

In-Text Citation: (Yaakub et al., 2020)

To Cite this Article: Yaakub, Z., Kusrin, Z. M., Nasohah, Z., \& Yusof, W. (2020). Thematic Study on Extrinsic Factors of Sexual Misconduct by Individuals with Autism. International Journal of Academic Research in Business and Social Sciences, 10(6), 1033-1045.

Copyright: (c) 2020 The Author(s)

Published by Human Resource Management Academic Research Society (www.hrmars.com)

This article is published under the Creative Commons Attribution (CC BY 4.0) license. Anyone may reproduce, distribute, translate and create derivative works of this article (for both commercial and non-commercial purposes), subject to full attribution to the original publication and authors. The full terms of this license may be seen at: http://creativecommons.org/licences/by/4.0/legalcode

Vol. 10, No. 6, 2020, Pg. 1033 - 1045

http://hrmars.com/index.php/pages/detail/IJARBSS

JOURNAL HOMEPAGE

Full Terms \& Conditions of access and use can be found at http://hrmars.com/index.php/pages/detail/publication-ethics 


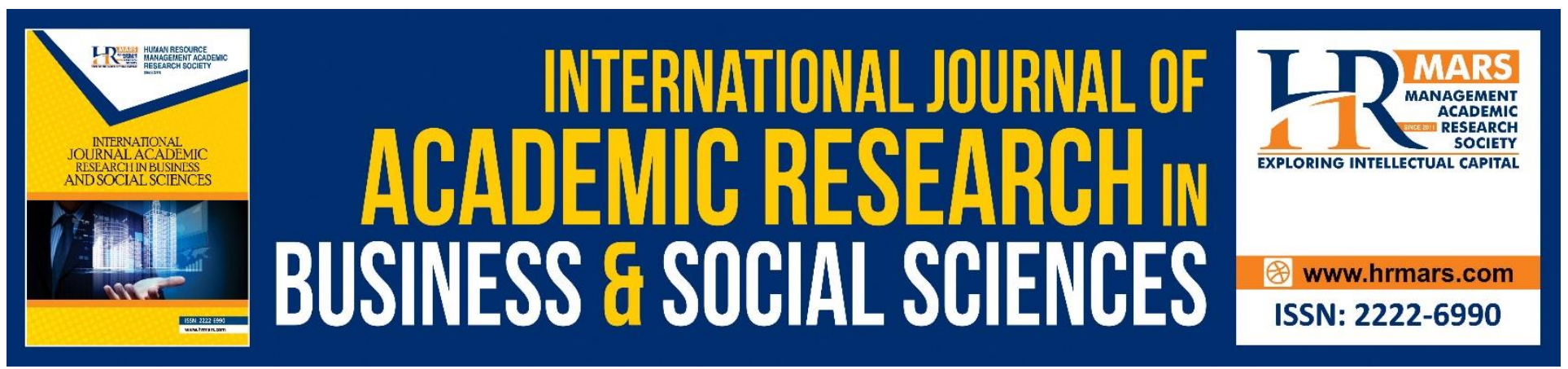

\title{
Thematic Study on Extrinsic Factors of Sexual Misconduct by Individuals with Autism
}

\author{
Zuraini Yaakub, Zuliza Mohd Kusrin, Zaini Nasohah, Wafaa' Yusof \\ Centre for Contemporary Fiqh and Islamic Compliance, National University of Malaysia (UKM), \\ 43600 Bangi, Selangor.
}

\begin{abstract}
Autism commonly refers to neurological developmental disorder that affects communication and behavior of individual. The characteristics of autism are mainly communication impairments and restricted repetitive behaviours. However, there is another autism unique characteristic often associated with interest in sexual interaction and behavior. It is believed that sexual misconduct by individuals with autism indicates symptoms of sexual victimization that they experience. Realizing the absence of systematic literature review focusing on extrinsic factors that cause Autism spectrum disorder (ASD) individuals to behave sexually, hence this study is based on the belief that there are extrinsic factors that cause individuals with autism to engage in sexual misconduct. This article aims to synthesize literature dated from 2000 to 2020 using ATLAS.ti 8 to answer research question of this study. The researchers have used keyword search, followed by filters using criteria from SCOPUS, Science Direct and Mendeley which resulted to 30 peer-reviewed journal articles. Next is the inclusive and exclusive process with selection of 24 articles as final articles for study review. The thematic study of 24 articles have identified 52 early codes on extrinsic factors causing ASD offenders involved in sexual misconduct. The codes are categorized into four groups namely sexual abuse, lack of sexuality education, social misconception and pornography. The study proposes that there should be early intervention and education in sexuality for ASD community to alleviate negative elements that may intensify sexual symptoms among individuals with autism.
\end{abstract}

Keywords: Autism, Sexual, Abuse, Misinterpretation, Pornography.

\section{Introduction}

Autism is a neurological developmental disorder that affects psychological and behavioral development of the individual experiencing it. According to the Diagnostic and Statistical Manual of Mental Health Disorders (DSM-5) (2013), individuals with autism are classified into three functional level: autism level 1, autism level 2 and autism level 3 (Harstad et al. 2015). Autistic individuals at level 1 generally have the mildest symptoms and require minimal support to funtion in their daily activities. Also being referred as High Functioning Autism (HFA), the individuals often have good language skills, high IQ and proficiency in matters of logic and visual thinking (Worthington, 2019). Nonetheless, they may face difficulty to initiate social interaction and prefer to stick to their routines 
rather than accepting changes. While level 2 refers to middle level of autism which requires more support in particular areas compared to level 1. Individuals at level 2 may face difficulty in their verbal communication and non verbal behaviour. They also struggle in their restrictive or repetitive behaviour. The most severe of autism is at level 3 whereby the individuals need the most support to perform their daily activities. They face extreme difficulty in communicating, establishing contact and changing their daily routines. Nevertheless, their capability and inability depend on more or less deficit that they experience (Mouridsen, 2012). It is possible that an individual with autism has little social ability, high in his social understanding but could be low in speech (Hasnah 2017). Hence the three levels of autism provide more clarity on different capabilities and needs of individuals with autism.

Research on autism has recently gained a lot of attention. This situation directly raises public awareness on autism spectrum disorders (ASD) including the need in handling ASD individuals and necessary intervention in helping the autism community. Moreover, sexual misconduct among ASD individuals has also been the focus of further research following cases of autistic individual detained, put under trial on sexual misconduct charges, convicted and penalized (Mastura, 2018; Freckelton 2013, Fedor, 2018). Therefore, research on extrinsic factors contributing to sexual misconduct among individuals with autism should be carried out further due to absence of literature review concerning matters of this issue. Advanced research is crucial for better understanding of autism community, especially those involved with the legal justice system. This article will carry out systematic literature review on extrinsic factors that cause individuals with autism to involve in sexual misbehaviour.

RQ: With reference to literary works published from 2000 to 2020, what are the extrinsic factors that cause individuals with autism to involve in sexual misconduct?

\section{Methodology}

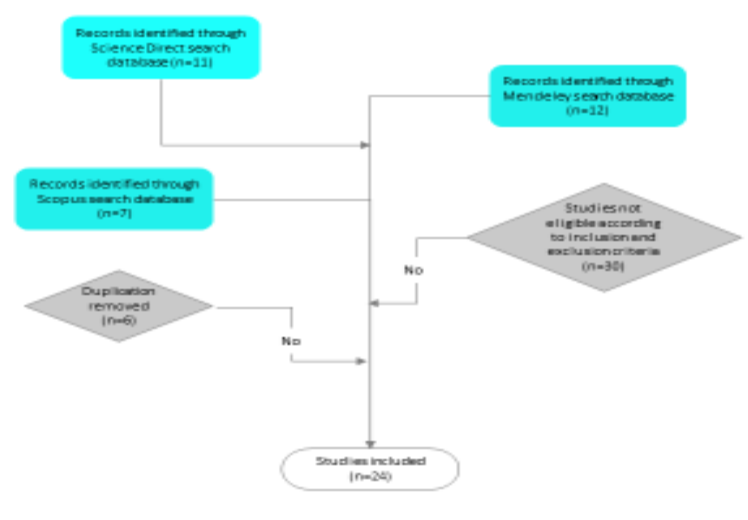

Figure 1: Inclusive and Exclusive Criteria

The first step for article review is to search for current academic insights on autism and sexual behavior. Published articles that can be accessed will be extracted from Science Direct using keywords "Autism" AND "Sexual Offendors" as well as Scopus using keywords TITLE-ABS-KEY ("Autism" AND "inappropriate sexual behaviors") AND PUBYEAR- 2000 to 2020 , TITLE-ABS-KEY 
INTERNATIONAL JOURNAL OF ACADEMIC RESEARCH IN BUSINESS AND SOCIAL SCIENCES Vol. 10, No. 6, June, 2020, E-ISSN: 2222-6990 @ 2020 HRMARS

("Autism" AND "stalking") AND PUBYEAR - 2000 -2020. The Mendeley database is also used to extract Elsevier publications using keyword "Autism" AND sexual crime year: [2000 TO 2020]. This process resulted to selection of 30 publications from the three databases. However 6 publications were removed since this study takes only reviewed journals and theses. The remaining 24 works, which were published from year 2000 to 2020 were then considered for review purpose.

Literary works that are not related to sexual misconduct factors will be considered as irrelevant since the focus is mainly on factors contributing to sexual misconduct by autistic individuals (see Figure 1). Subsequently, all 24 metadata were transferred to ATLAS.ti 8 to serve as primary document. From the metadata established in Mendeley, several groups were generated automatically as shown in Figure 2. Classification in ATLAS.ti has made filtering easier and systematic. In the first round of encoding, 52 startup codes are issued. The code was then grouped into several themes and answered the research question, "With reference to literary works published from 2000 to 2020, what are the extrinsic factors that cause individuals with autism to involve in sexual misconduct?" The findings of this study will be divided into two parts: quantitative and qualitative findings.

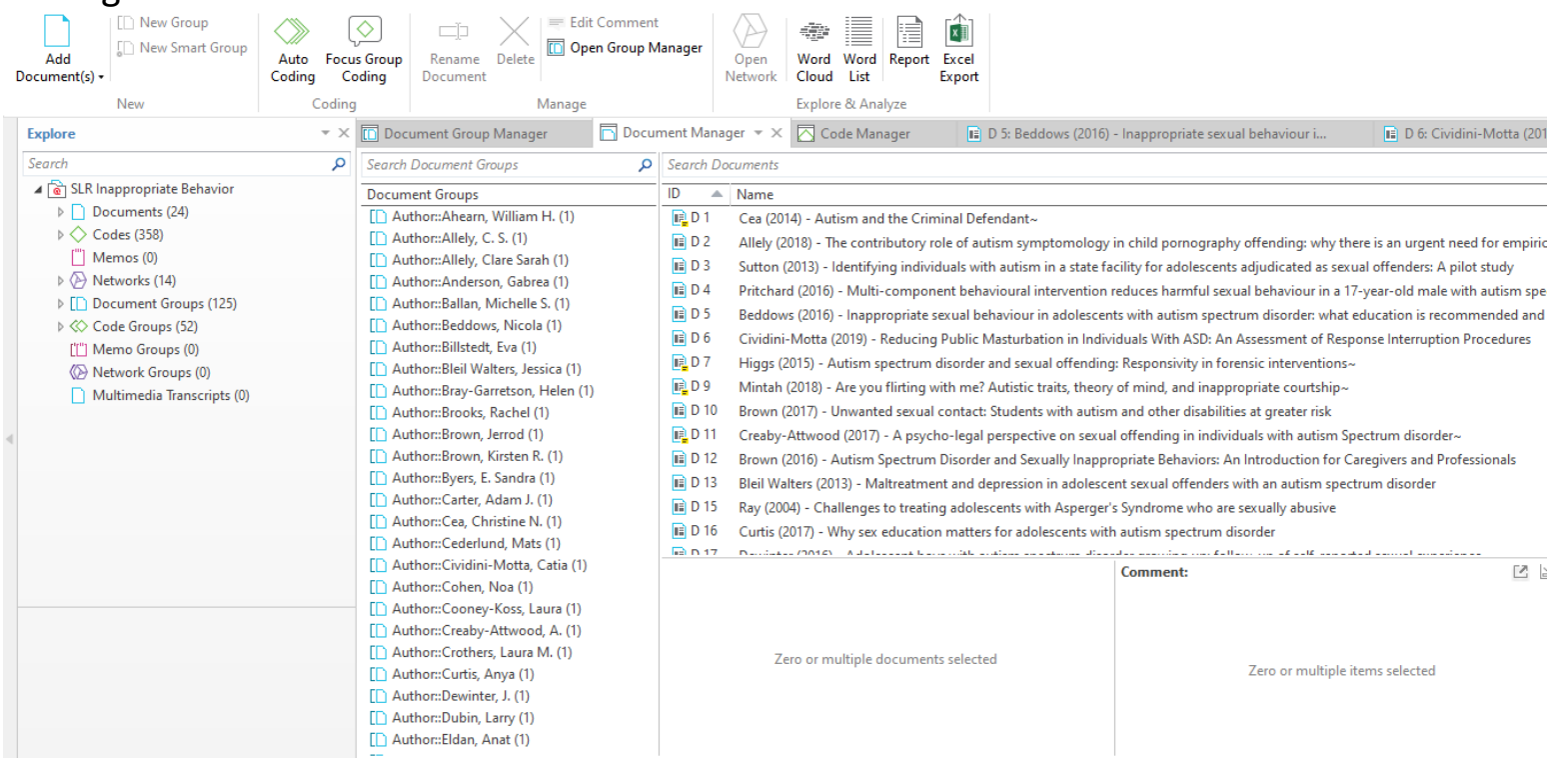

\section{Findings and Discussion Quantitative Finding}

Since the search in the database is static and using the phrase "Autism" OR "sexual behavior" OR 'sexual crime' resulted to limited finding, proceedings and theses were then included to assess form and pattern. Although the search for articles was mainly on autism and sexual misconduct or a factor linking autism to sexual misconduct, it appears that a collection of journals lists various published articles. This research structure refers directly to the 24 articles identified through several publications namely Journal of Autism, Journal of Intellectual Disabilities and Offending Behavior, Sexuality Disability, Journal of Child Sexual Abuse and others (Table 1). The process further continues with a critical study on findings of sexual misconduct cases involving individuals with autism. 
INTERNATIONAL JOURNAL OF ACADEMIC RESEARCH IN BUSINESS AND SOCIAL SCIENCES Vol. 10, No. 6, June, 2020, E-ISSN: 2222-6990 @ 2020 HRMARS

Table 1: Reviewed articles based on research journal

$\begin{array}{lllllllllll}2004 & 201 & 201 & 201 & 201 & 201 & 201 & 201 & 201 & 201 & 202 \\ & 1 & 2 & 3 & 4 & 5 & 6 & 7 & 8 & 9 & 0\end{array}$

St John's and Law

$\begin{array}{llll}1 & 2 & 3 & 4\end{array}$

Review

Journal of

Intellectual

Disabilities and

Offending Behaviors

Hammill Institute on

1

Disabilities

Journal Of Sexual

Aggression

Early Intervention in

Psychiatry

Behavior 1

5

Modification

Aggression and

Violent Behavior

Personality and

Individual

Differences

Journal of College

Student

Devolopment

International Journal

of Law and

Psychiatry

Journal Of Special

Populations

Journal of Child

Sexual Abuse

Sexual Addiction \&

Compulsivity

American Journal of

Nursing

Eur Child Adolesc

Psychiatry

Sexuality and

Disability

Autism

Develepmental

Disorders

1

1

1

1

1

1

1
1

1

1

1

1

2

11

1

2

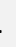


INTERNATIONAL JOURNAL OF ACADEMIC RESEARCH IN BUSINESS AND SOCIAL SCIENCES

Vol. 10, No. 6, June, 2020, E-ISSN: 2222-6990 @ 2020 HRMARS

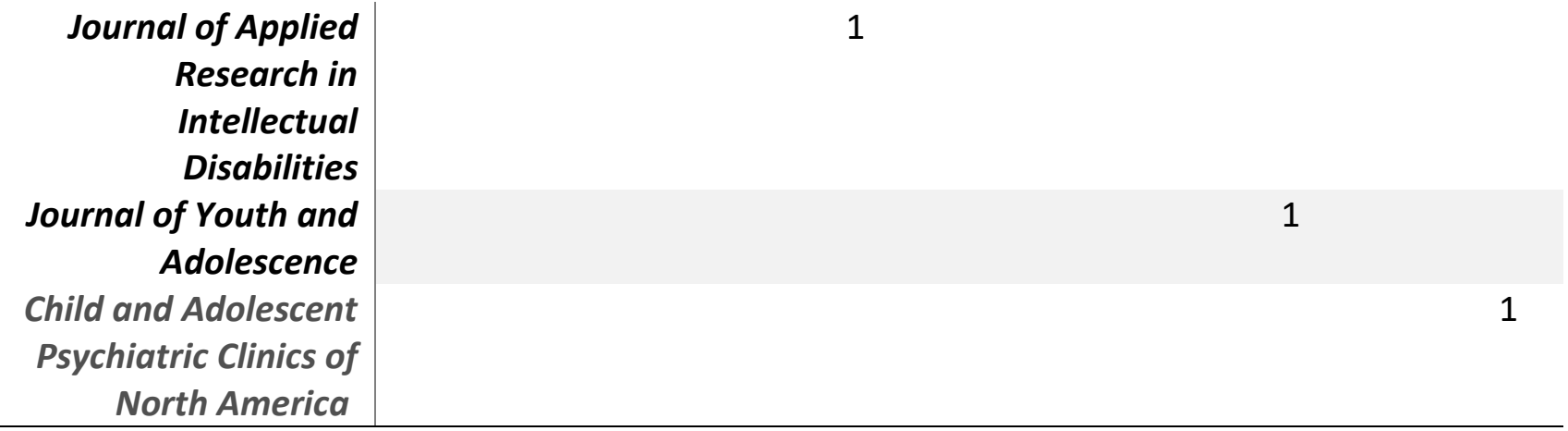

Data from Table 1 shows an overall increase of publications on subject concerning autism. From 2000 to 2010, only few works on autism and sexual misconduct being published. However, the number gradually improve every year especially in 2017. At the time this article was written, there was 1 article published in 2020; possibly there will be more articles coming in since they are still in the process of completion. The researcher is aware that most of the journals do not address the major concerns of this study particularly studies on treatment, genetic factors and communication mechanisms of individuals with autism which have been screened earlier.

The selected 24 research articles were reviewed in an iterative process through comparisons of similarities and differences to achieve consistency in the generated sub-categories. The list of publications and their themes in sub-categories can be found in table 2. This study focuses only on the extrinsic factors that contribute to sexual misconduct of individuals with autism. The initial encoding of the 52 codes was further classified into 4 main themes namely sexual abuse, misinterpretation of society, lack of sexuality education, and pornography (Table 2). 
INTERNATIONAL JOURNAL OF ACADEMIC RESEARCH IN BUSINESS AND SOCIAL SCIENCES Vol. 10, No. 6, June, 2020, E-ISSN: 2222-6990 @ 2020 HRMARS

Table 2: Documents with reference to theme tables

\begin{tabular}{|c|c|c|c|c|}
\hline & 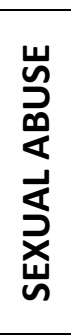 & 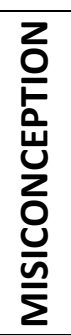 & 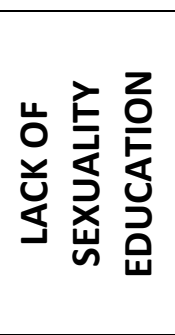 & 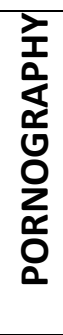 \\
\hline Cea (2014) & & & & I \\
\hline Allely (2018) & & & & I \\
\hline Sutton (2013) & & & I & \\
\hline Pritchard (2016) & & & I & \\
\hline Beddows (2016) & I & & I & I \\
\hline Cividini-Motta (2019) & l & & I & \\
\hline Higgs (2015) & & / & I & \\
\hline Mintah (2018) & I & & & \\
\hline Brown, Peña, Rankin - 2017 & & & / & \\
\hline Creaby-Attwood (2017) & & I & & \\
\hline Brown (2016) & I & & & \\
\hline Bleil Walters (2013) & l & & I & \\
\hline Ray (2004) & & & I & I \\
\hline Curtis (2017) & & & I & \\
\hline Dewinter (2016) & & & / & \\
\hline Byers (2013) & & & I & I \\
\hline Sevlever (2013) & I & & I & \\
\hline Pearlman-Avnion (2017) & & I & & \\
\hline Fernandes (2016) & & & I & \\
\hline Ballan (2017) & & & I & \\
\hline Freckelton 2013 & I & I & I & I \\
\hline Pecora (2020) & I & & I & \\
\hline Holmes (2014) & & & I & \\
\hline Fedor (2018) & & I & & \\
\hline
\end{tabular}


INTERNATIONAL JOURNAL OF ACADEMIC RESEARCH IN BUSINESS AND SOCIAL SCIENCES Vol. 10, No. 6, June, 2020, E-ISSN: 2222-6990 @ 2020 HRMARS

\section{Qualitative Finding}

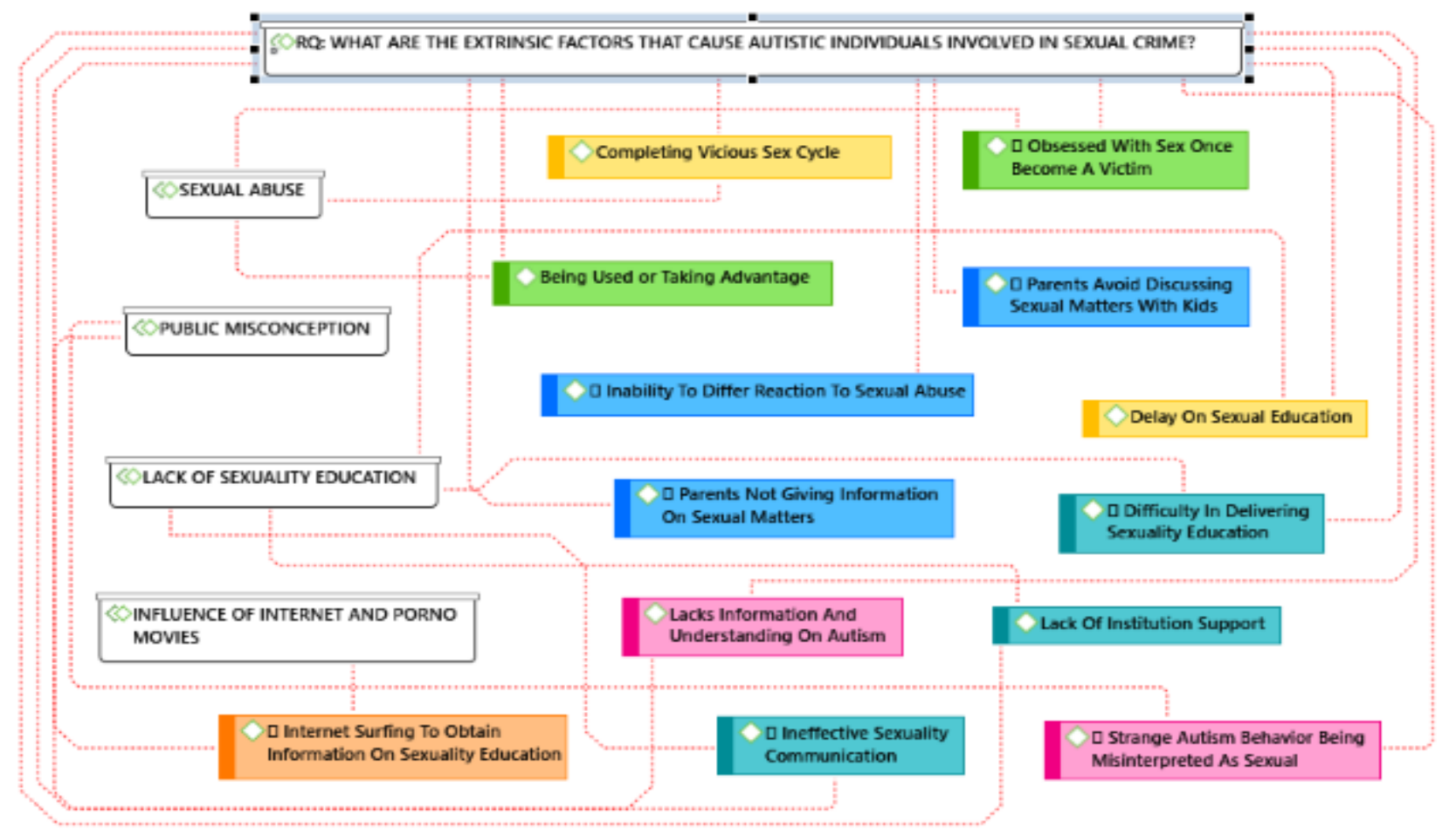

\section{a. Sexual Abuse}

A study by Curtis (2017) addressed that sexual misbehavior by individuals with autism are indicative of symptoms on sexual victimization that they have experienced. There is possibility that autistic individuals became victim to sexual offenders and unintentionally try to imitate or show what they have experienced to others. Symptoms of this vicious cycle are evidenced by a study by Sutton et al., (2013) who found that autistic sexual offenders have been exposed to childhood sexual abuse experiences. These symptoms have led to some of them becoming obsessed with sexual activity while others are experiencing other psychopathology that will continue to associate autistic individuals with sexual misconduct (Walters et al., 2013). Sexual abuse also confuses ASD individuals who misunderstood that sexual contact is part of social relationships (Ray et al. 2004). Although sexual acts are committed without intent and may not be recognized as a crime, the ASD offenders still perceived as violating norms of society (Creaby-Attwood \& Allely, 2017). Therefore, an in-depth study on other psychopathology and secondary characteristics of autistic individuals leading to sexual misbehavior should be carried out further to identify its relationship to sexual misconduct. 
INTERNATIONAL JOURNAL OF ACADEMIC RESEARCH IN BUSINESS AND SOCIAL SCIENCES Vol. 10, No. 6, June, 2020, E-ISSN: 2222-6990 @ 2020 HRMARS

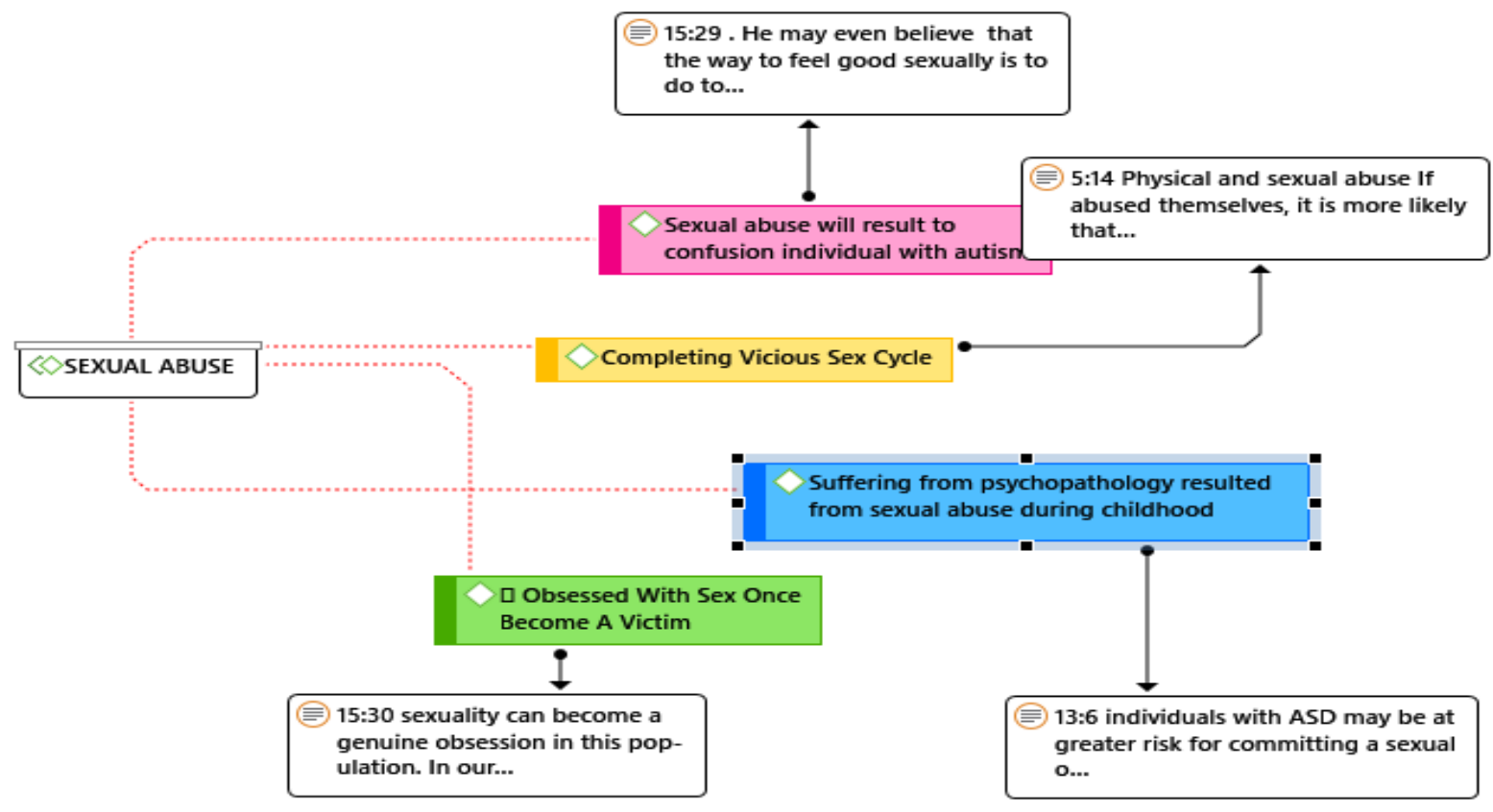

\section{b. Lack of Sexuality Education}

According to Dewinter et al (2016), parents are less concerned about the sexual encounter experienced by their teenagers who are struggling with autism disorders. This situation causes ASD individuals to experience puberty alone and has no guidance on masturbation and orgasm. The lack of sexuality education is also reflected in the difficulty of providing information about sexual matters to individuals with autism (Brown et al. 2017). Education in sexuality must be communicated to individuals with autism directly, accurately, openly and formally (Sevlever et al., 2013). The terms used need to be clear and do not use covert terms because they hardly understand covert language in discussing sexual matter.

Additionally, sexuality education for ASD individuals is often an issue when there is a delay in the diagnosis process (Higgs \& Carter, 2015). This is often the case for some individuals with HFAs who are at level 1 that are having mens rea and may be convicted if found guilty of committing a crime (Freckelton, 2013). Delay in the diagnosis process will result in late implementation of special sexuality education interventions for ASD individuals until a sexual misconduct is committed (Curtis, 2017). Although ASD individuals at level 1 are HFA who are capable of having sexual relations (Beddows \& Brooks 2016) and having mens rea (Freckelton, 2013), these individuals are still struggling to distinguish between what can and cannot be done (Pearlman et al., 2017). Therefore there is a need for advanced studies to further examine the extent of individuals with autism to accept criminal liability once they are involved in sexual misconduct. 
INTERNATIONAL JOURNAL OF ACADEMIC RESEARCH IN BUSINESS AND SOCIAL SCIENCES Vol. 10, No. 6, June, 2020, E-ISSN: 2222-6990 @ 2020 HRMARS

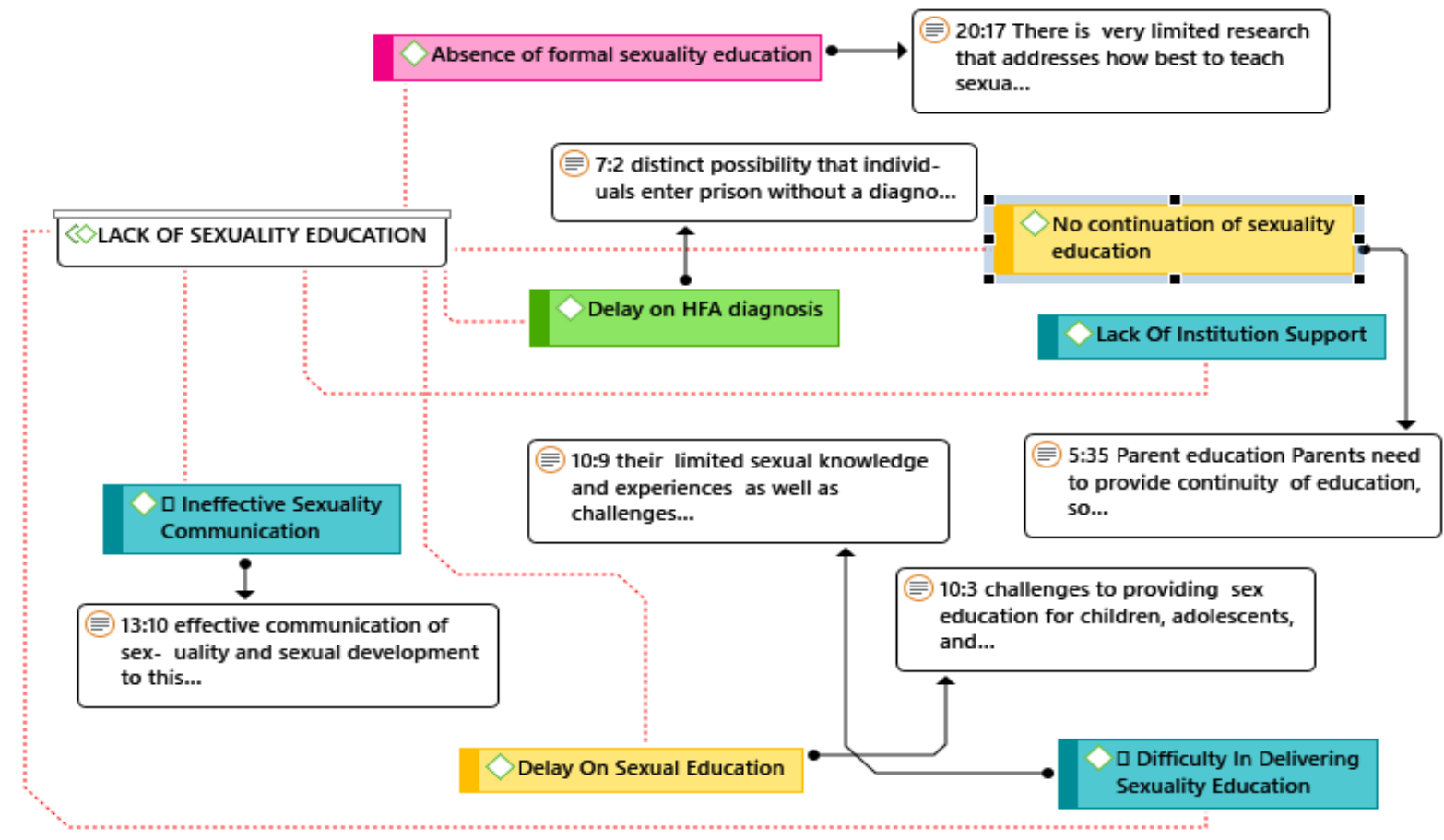

\section{c. Public Misconception}

According to (Brewer \& Young 2015), social misconceptions often happen when individuals with autism are easily mistaken as being sexually active. This misconception happens when ASD individuals are exposed to sexual behavior shown to them and unintentionally imitate such behaviour. For example, individuals with autism are considered stalking while they are actually trying to be social (Mintah \& Parlow, 2018). Similarly, when individuals with autism try to calm down by stimming, it is often assumed that sexual stimulation is taking place (Creaby-Attwood \& Allely, 2017).

Misconceptions in society are also serious when it comes to criminal justice systems. According to a book review by Fedor (2018), individuals with autism are often referred as individuals who behave strangely or have mental problem when involved in sexual misconduct. Therefore, in the absence of eye contact, individuals with autism are considered lying when they testify. Although it is undeniable that individuals with autism may engage in sexual misconduct due to their sexual desire (Brown et al., 2017), autism should be understood as autism with its own symptoms. It is therefore necessary to further study the secondary features and symptoms of autism that making them appear to be sexual criminals on misbehavior that they never intend to commit. 
INTERNATIONAL JOURNAL OF ACADEMIC RESEARCH IN BUSINESS AND SOCIAL SCIENCES Vol. 10, No. 6, June, 2020, E-ISSN: 2222-6990 @ 2020 HRMARS

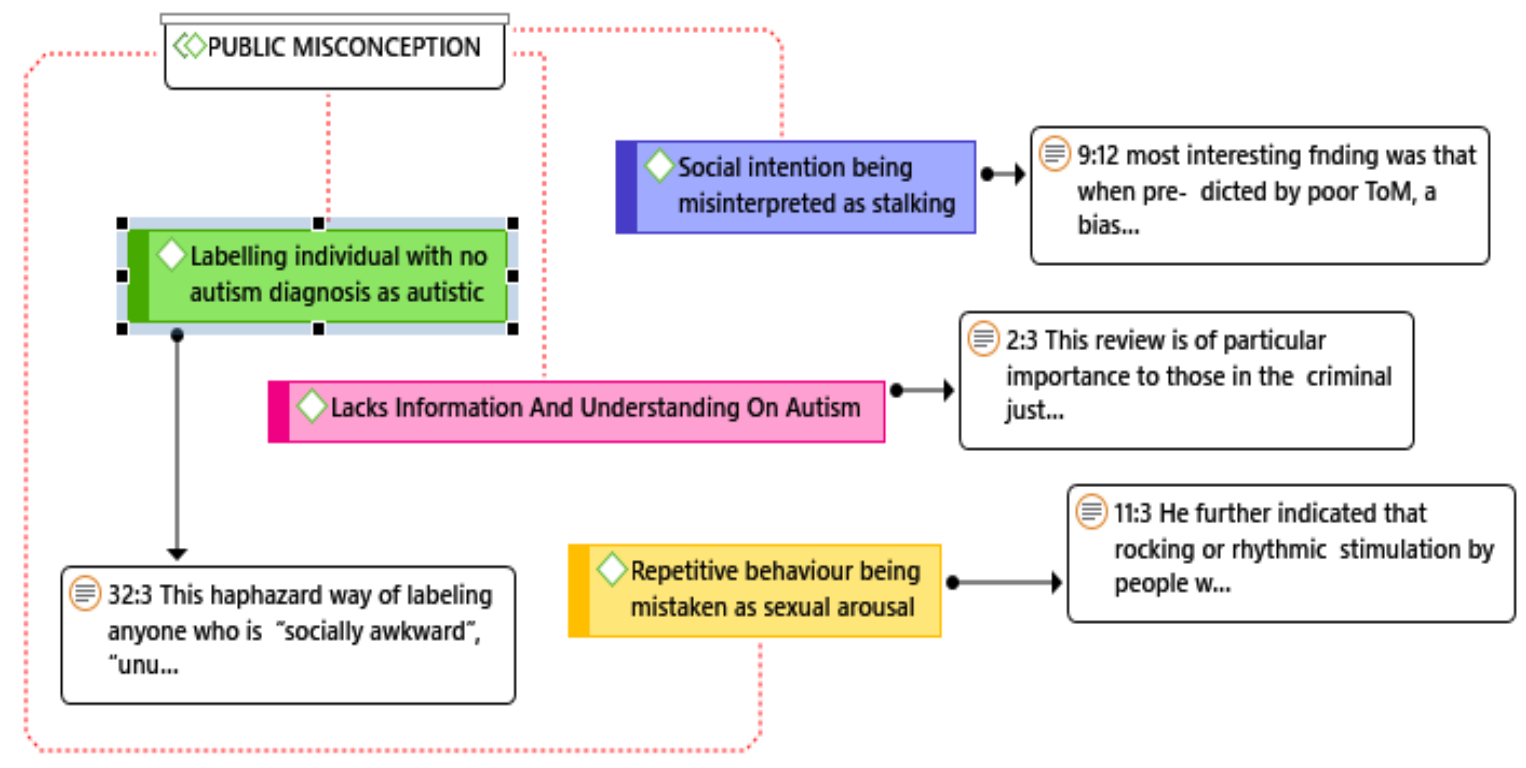

\section{d. Pornography}

Most people with autism receive information about sex on the internet, television and pornography compared to parents, friends and teachers following the stigma of community on sexual issues (Curtis 2017) as well as being difficult to interact with their peers (Allely \& Dubin, 2018). The portrayal of sexuality and intimacy from such sources may not be appropriate (Higgs \& Carter 2015), but it is possible that the information absorbed by individuals with autism about sex is completely misleading (Beddows \& Brooks 2016). For example, individuals with autism who watch child pornography on the internet are less likely to understand that sexual activity with children is criminal (Allely \& Dubin, 2018) thus attempt to practice such sexual activity with children (Ray et al., 2004). The involvement of individuals with autism with child sexual abuse dragged the individual into more dangerous situations due to charges against the child would result in more severe penalties. In addition, leakage of information about sex on the Internet not only causes individuals with autism to be exposed as victims or perpetrators of sexual crimes but also to drag them into civilian crimes by possessing pornographic images of civil crimes under Section 292 of Act 574 of the Penal Code in Malaysia (Penal Code Malaysia). It is therefore necessary to review the existing laws that protect individuals with autism owing to the fact that there are no specific laws for ASD offenders in Malaysia.

\section{Conclusion}

There has been increasing of numbers in research on inappropriate sexual behavior among individuals with autism and the finding indicates that sexual misbehavior among autistic offenders is an increasingly popular issue. Four extrinsic factors on sexual misconduct among autistic offenders namely sexual abuse, lack of sexuality education, misconception of society and pornography have been discussed. Most articles under review focus on the gaps in sexuality education and follow the suggested behavior modification techniques that should be implemented. Only a small number of articles explain other factors, such as public misconception about the symptoms of autism and pornography. Although some findings addressed lack of sexuality education as a major extrinsic factor that may cause sexual misconduct among autistic offenders, research on aspects of autistic individuals' position in accepting criminal liability for such misbehavior is rarely discussed. In fact, 
INTERNATIONAL JOURNAL OF ACADEMIC RESEARCH IN BUSINESS AND SOCIAL SCIENCES

Vol. 10, No. 6, June, 2020, E-ISSN: 2222-6990 @ 2020 HRMARS

there is no systematic studies on sexual crimes involving autistic offenders despite their inability to understand and process sexual information exposed to them.

\section{Recommendation for Advanced Study}

First, there is a pressing need for more studies on factors for sexual misconduct among autistic offenders with more focus to be given on challenges of secondary issues. More discussions should also be carried out on some of the common ASD symptoms such as stimming, zoning out, mind blindness and psychiatric comorbidity to understand autism better.

Second, future works should also focus on abroad cases regarding sexual crimes involving individuals with autism as perpetrators. Such case study is necessary as a guide to establish position and criminal liability of individuals with autism involved in sexual misconduct.

Third, following the absence of specific legal provisions for autism community in Malaysia, studies on autism would be further enriched with investigation on existing legal rights that protect individuals with autism as part of disabled people community in the country.

\section{Corresponding Author}

Zuraini Yaakub

Centre for Contemporary Fiqh and Islamic Compliance, National University of Malaysia (UKM), 43600 Bangi, Selangor.

Email: zurainiyaakub96@gmail.com

\section{References}

Allely, C. S., \& Dubin, L. (2018). The contributory role of autism symptomology in child pornography offending: why there is an urgent need for empirical research in this area. Journal of Intellectual Disabilities and Offending Behaviour, 9(4), 129-152. https://doi.org/10.1108/JIDOB-06-20180008

Beddows, N., \& Brooks, R. (2016). Inappropriate sexual behaviour in adolescents with autism spectrum disorder: what education is recommended and why. Early Intervention in Psychiatry, 10(4), 282-289. https://doi.org/10.1111/eip.12265

Walters, B. J., Hughes, T. L., Sutton, L. R., Marshall, S. N., Crothers, L. M., Lehman, C., \& Huang, A. (2013). Maltreatment and depression in adolescent sexual offenders with an autism spectrum disorder. Journal of Child Sexual Abuse, 22(1), 72-89.

https://doi.org/10.1080/10538712.2013.735357

Brewer, N., \& Young, R. L. (2015). Crime and autism spectrum disoder: myths and mechanisms. Crime and Autism Spectrum Disorder. London: Philadelphia: Jessica Kingsley Publishers

Brown, K. R., Pena, E. V., \& Rankin, S. (2017). Unwanted sexual contact: Students with autism and other disabilities at greater risk. Journal of College Student Development, 58(5), 771-776. https://doi.org/10.1353/csd.2017.0059

Creaby-Attwood, A., \& Allely, C. S. (2017). A psycho-legal perspective on sexual offending in individuals with autism Spectrum disorder. International Journal of Law and Psychiatry, 55, 7280. https://doi.org/10.1016/j.ijlp.2017.10.009

Curtis, A. (2017). Why sex education matters for adolescents with autism spectrum disorder. American Journal of Nursing, Vol. 117, p. 11. https://doi.org/10.1097/01.NAJ.0000520233.91525.1f 
INTERNATIONAL JOURNAL OF ACADEMIC RESEARCH IN BUSINESS AND SOCIAL SCIENCES

Vol. 10, No. 6, June, 2020, E-ISSN: 2222-6990 @ 2020 HRMARS

Fedor, K. (2018). Neil Brewer and Robyn L. Young: Crime and Autism Spectrum Disorder: Myths and Mechanisms. Journal of Youth and Adolescence, 47(5), 1133-1135.

https://doi.org/10.1007/s10964-018-0833-6

Freckelton, I. (2013). Autism spectrum disorder: Forensic issues and challenges for mental health professionals and courts. Journal of Applied Research in Intellectual Disabilities, 26(5), 420-434. https://doi.org/10.1111/jar.12036

Harstad, B. E., Fogler, J., Sideridis, G., Weas, S., Mauras, C., Barbaresi, W. J. (2015). Comparing Diagnostic Outcomes of Autism Spectrum Disorder Using DSM-IV-TR and DSM-5 Criteria. Journal Autism Dev Disord. 45:1437-1450

Toran, H. (2017). A Complete Guide to Parenting Children with Autism. Riyadh: Kuala Lumpur.

Higgs, T., \& Carter, A. J. (2015). Autism spectrum disorder and sexual offending: Responsivity in forensic interventions. Aggression and Violent Behavior, 22, 112-119. https://doi.org/10.1016/j.avb.2015.04.003

Mastura M. S. (2018). Status of the Accused with Autism Spectrum Disorder According to the West and Islamic Criminal Law. Master Thesis. Bangi: UKM.

Mintah, K., \& Parlow, S. E. (2018). Are you flirting with me? Autistic traits, theory of mind, and inappropriate courtship. Personality and Individual Differences, 128(February), 100-106. https://doi.org/10.1016/j.paid.2018.02.028

Mouridsen, S. E. (2012). Current status of research on autism spectrum disorders and offending. Research in Autism Spectrum Disorders, 6, 79-86. https://doi.org/10.1016/j.rasd.2011.09.003

Ray, F., Marks, C., \& Bray-Garretson, H. (2004). Challenges to treating adolescents with Asperger's Syndrome who are sexually abusive. Sexual Addiction and Compulsivity, 11(4), 265-285. https://doi.org/10.1080/10720160490900614

Sevlever, M., Roth, M. E., \& Gillis, J. M. (2013). Sexual Abuse and Offending in Autism Spectrum Disorders. Sexuality and Disability, 31(2), 189-200. https://doi.org/10.1007/s11195-013-9286-8

Sutton, L. R., Hughes, T. L., Huang, A., Lehman, C., Paserba, D., Talkington, V., ... Marshall, S. (2013). Identifying individuals with autism in a state facility for adolescents adjudicated as sexual offenders: A pilot study. Focus on Autism and Other Developmental Disabilities, 28(3), 175-183. https://doi.org/10.1177/1088357612462060

Worthington, R. (2019). The multi-component model of harmful sexual behaviour for people with autism and co-morbid intellectual disabilities - a theory and practice guide. Journal of Forensic Practice, 21(1), 1-13. https://doi.org/10.1108/JFP-07-2017-0027

Pearlman-Avnion, S., Cohen, N., \& Eldan, A. (2017). Sexual Well-Being and Quality of Life Among HighFunctioning Adults with Autism. Sexuality and Disability, 35(3), 279-293. https://doi.org/10.1007/s11195-017-9490-z 